\title{
Study on the Application of Bicycle Special Routes as an Environmental Transportation in the City Area of Palembang Using The Blos Method
}

\author{
Efrilia Rahmadona ${ }^{1, *}$ Norca Praditya ${ }^{1}$ M. Ade Surya Pratama ${ }^{1}$ \\ Sudarmadji Sudarmadji ${ }^{1}$ Muhammad Iqbal ${ }^{1}$ Arief Perdana Kesuma ${ }^{1}$ Rica Solenne ${ }^{1}$ \\ ${ }^{1}$ State Polytechnic of Srwiwijaya \\ *Corresponding author. Email: efriliarahmadona@polsri.ac.id
}

\begin{abstract}
The special bicycle lane has been inaugurated by the Palembang city government, the mayor of Palembang, in 2020 where the lane is divided into three official routes for bicycle lanes. The government's purpose to build these three special bicycle lanes is to regulate traffic flow and facilitate cyclists in the city of Palembang. In its application, there are still many obstacles in the use of this special bicycle lane as a result of the large volume of private vehicles which are dominated by motorized vehicles. In addition, these obstacles also arise due to the minimal number of bicycle users and the purpose of cycling which is still limited only to exercise. The purpose of this study was to analyze the effectiveness of special bicycle lanes in the city of Palembang using quantitative descriptive methods and analytical methods with BLOS (Bicycle Level Of Service) techniques. Data was collected through a survey method. The results of the research and analysis with BLOS obtained on Mondays at $06.00-0.8 .00,16.00-18.00$ and Sundays at 16.00 18.00 are in the form of BLOS values, which found to be in the "F" rank, which is more than 5.5. This indicates that the environment is not safe to use as a bicycle lane. Meanwhile, the results obtained on Mondays at $11.00-13.00$ and Sundays at $06.00-08.00,16.00-18.00$ show the BLOS value which is ranked "E" which means the environment has insufficient space for cyclists.
\end{abstract}

Keywords: BLOS, effectiveness, bicycle lane

\section{INTRODUCTION}

The Palembang City Government considers that the trend of cycling continues to increase during this pandemic so that support from the government appears in this regard by providing special bicycle lanes in Palembang City. Special bicycle lanes have been stipulated in Law No. 22 of 2009 concerning Road Traffic and Transportation. In the law, it is stated that every road used for public traffic must be equipped with road equipment in the form of facilities for bicycles, pedestrians, and people with disabilities (Article 25). In addition, the article also explains that supporting facilities for road traffic and transportation include bicycle lanes (Article 45) where the government must provide easy traffic for cyclists. This means that cyclists have the right to support facilities for security, safety, order, and smoothness in traffic (Article 62). In 2020, the Mayor of Palembang inaugurated three special bicycle lane routes in Palembang City. These three special lanes for cyclists were created by the Palembang city government to regulate traffic flow (Kompas, 2020). The application of this special bicycle lane will certainly not succeed without efforts to reduce the volume of private vehicles (Artiningsih, 2011). Based on previous research, it was found that the current purpose of cycling society is only to exercise (Praditya N et al, 2020). From this research, it is hoped that in the future, the use of bicycles or non-motorized vehicles can be used as transportation for daily activities, such as working to reduce the dominance of private motorized vehicles, namely through the use of non-motorized vehicles which can then be slowly integrated into public transportation such as already available, BRT and LRT.

The application the use of special bicycle lanes in the urban area of Palembang is still experiencing difficulties due to the large volume of private vehicles which are dominated by motorized vehicles. Furthermore, the 
implementation of bicycle lanes will certainly not succeed without efforts to reduce the volume of private vehicles and improve non-motorized vehicle facilities, especially bicycles (Fadly, G., Widodo, S. and Mayuni, $\mathrm{S})$. After the Palembang City government provides a special bicycle lane which is divided into three routes, Palembang City in the future is expected to have other supporting facilities for bicycle users, such as the provision of special bicycle parking and a park and ride system that can facilitate integration access to available public transportation. Therefore, it is necessary to study the effectiveness of the application of existing bicycle lanes so that it can be known the effect of bicycle lane performance on motorized vehicle lanes. Studies related to the effectiveness of the implementation of special bicycle lanes in the city of Palembang also need to be carried out, so that the Palembang City Government has a reference to develop other supporting facilities.

\section{LITERATURE REVIEW}

\subsection{Bicycle Lane}

The bicycle lane is a special lane intended for bicycle traffic which is separated from motorized vehicle traffic to maintain the safety of bicycle traffic. Bicycle lanes have been stated in Law No. 22 of 2009 which contains Road Traffic and Transportation. In the law, it is stated that every road used for public traffic must be equipped with road equipment as facilities for bicycles, pedestrians, and people with disabilities (Article 25).

\subsection{Bike Lane Service Level}

BLOS (Bicycle Level Of Service) is a method for evaluating the service level of bicycle lanes along with the factors that influence it, such as road width, traffic volume, pavement conditions, bicycle lane width and other vehicle speeds. ,

The formula for calculating the bicycle service level is as follows (HCM, 2010):

$\mathrm{BLOS}=0.760+\mathrm{Fv}+\mathrm{Fs}+\mathrm{Fp}+\mathrm{Fw}$

Table 1. Bicycle Level of Service

\begin{tabular}{|l|l|l|l|}
\hline No & \multicolumn{1}{|c|}{ Description } & $\begin{array}{l}\text { BLOS } \\
\text { Value }\end{array}$ & $\begin{array}{l}\text { BLOS } \\
\text { Rating }\end{array}$ \\
\hline 1 & $\begin{array}{l}\text { The environment is very } \\
\text { good for bicycle }\end{array}$ & $\leq 1.5$ & A \\
\hline 2 & $\begin{array}{l}\text { The environment is good } \\
\text { for bicycle }\end{array}$ & $\begin{array}{l}\text { The environment is quite } \\
\text { good for bicycle } \\
\text { acceptable by } \\
\text { experienced cyclist and } \\
\text { basic cyclist) }\end{array}$ & B \\
\hline
\end{tabular}

\begin{tabular}{|l|l|l|l|}
\hline 4 & $\begin{array}{l}\text { The environment is less } \\
\text { good for bicycle } \\
\text { (acceptable by } \\
\text { experienced cyclist) }\end{array}$ & D \\
\hline 5 & $\begin{array}{l}\text { The environment is } \\
\text { strongly poor for bicycle } \\
\text { (unacceptable by } \\
\text { experienced cyclist and } \\
\text { basic cyclist) }\end{array}$ & $\begin{array}{l}\text { E } \\
\text { The environment is } \\
\text { unsafe for bicycle (not } \\
\text { suitable for any cyclist) }\end{array}$ & P5.5 \\
\hline 6
\end{tabular}

\section{RESEARCH METHOD}

This study adopted a survey method using a questionnaire to determine the characteristics of cyclists. In this study, a traffic volume survey, vehicle speed survey, and road geometry data collection were carried out. The data was then processed and analyzed using the Bicycle Level of Service (BLOS) method.

\subsection{Traffic Volume}

The method used to collect the traffic volume data is through a traffic survey conducted for 1 week, namely on weekdays, (Monday) and weekends (Sunday), at 06.00 08.00 WIB, 11.00 - 13.00 WIB, and 16.00 - 18.00 WIB. Traffic volume formula:

$q=\frac{n}{t}$

where :

$\mathrm{q}=$ traffic volume,

$\mathrm{n}=$ number of vehicles,

$\mathrm{t}=$ time interval (hours, seconds)

\subsection{Motor Vehicle Speed}

Motor vehicle speed formula:

$V=\frac{s}{t}$

Where:

$\mathrm{V}=$ vehicle speed $(\mathrm{km} / \mathrm{hour}, \mathrm{m} / \mathrm{sec})$,

$\mathrm{S}=$ Distance $(\mathrm{km}, \mathrm{m})$,

$\mathrm{t}=$ time interval (hour, second)

In this study, the speed of the vehicle is known by using a speed gun, which is firing directly at vehicles passing by on the surveyed road segment to calculate the average speed.

\subsection{Pavement Width}

The following formula is the width of the bicycle lane pavement, namely:

$\mathrm{Wt}=\mathrm{Wol}+\mathrm{Wbl}$

Where:

$\mathrm{Wt}=$ total width,

Wol = travel lane width,

$\mathrm{Wbl}=$ bicycle lane width 
Type of Road Pavement Determination of the level of pavement is determined by the type of road pavement according to FHWA standards.

\subsection{Heavy Vehicles}

Analysis of the percentage of heavy vehicles (PHva) was carried out by dividing each heavy vehicle by the number of vehicle traffic flows per hour (Vma) and then multiplied by 100 .

\subsection{Bicycle Level Of Service (BLOS) Analysis}

The research method adopted quantitative descriptive analysis using Bicycle Level Of Service (BLOS) analysis techniques. The formula for calculating the service level of a bicycle is as follows:

$\mathrm{BLOS}=0,760+\mathrm{Fv}+\mathrm{Fs}+\mathrm{Fp}+\mathrm{Fw}$

Where

Constant $=0,760$

Volume factor $(\mathrm{Fv})=0,507 \ln (\mathrm{Vma} / 4 . \mathrm{Nth})$

Vma : Traffic flow (vehicles/hour)

Nth : Number of lanes in one way

$\mathrm{Wv}=\mathrm{Wt}$, If $\mathrm{Vma}>160$ Vehicles per hour.

Then, the variable when the condition is met:

$\mathrm{Wt}=\mathrm{Wol}+\mathrm{Wbl}+\mathrm{Wos}$ '

$\mathrm{We}=\mathrm{Wv}-10 \mathrm{Ppk}>0,00$

$\mathrm{Wv}=\mathrm{Wt}(2-0,00025 \mathrm{Vma})<160$

Vehicles per hour, and if the road/road is not full and not divided. Then the variable when the condition is not met: $\mathrm{Wt}=\mathrm{Wol}+\mathrm{Wbl}$

$\mathrm{We}=\mathrm{Wv}+\mathrm{Wbl}+\mathrm{Wos}^{\prime}-20 \mathrm{Ppk}>0,00$

Where Ppk $=$ On-street parking portion of the road width

Wos $=$ The width of parking on-street

Wos' $=$ The widthf of the adjusted parkir on-street

$\mathrm{Wbl}=$ Width of bicycle lane

Wol = Width of travel lane

$\mathrm{Wt}=$ Total width

$\mathrm{Wv}=$ Effective width

BLOS traffic volume in this case uses six scale ranges to describe the quality of road segments for bicycle trips, from the best to the worst conditions based on user perception. The description is presented in the table.

The width of the bicycle lane on Kambang Iwak Palembang Square is 1.5 meters and is on the right or left side of the road as shown in Figure 3. The condition of the bicycle lane is adjusted to the Regulation of the Minister of Transportation No. 34 of 2011 concerning RoadMarking.

\section{DISCUSSION}

\subsection{Characteristics of cyclists}

The results of the questionnaire from 250 respondents showed that the most age range of cyclists was in the age range of $36-45$ years, namely $40 \%$. Regarding the intensity of the use of bicycle lane routes, $78 \%$ of respondents stated that they often use bicycle lanes. The most dominating reason for using a bicycle is for sports facilities which are represented by a percentage of $84 \%$.

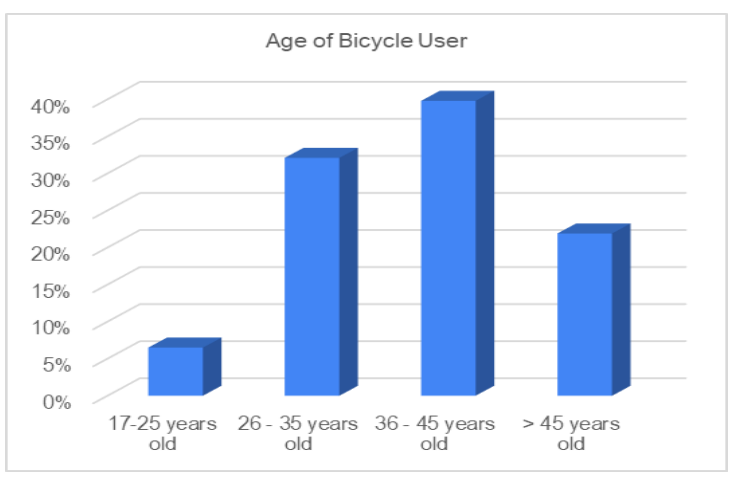

Figure 1. Age of bicycle user

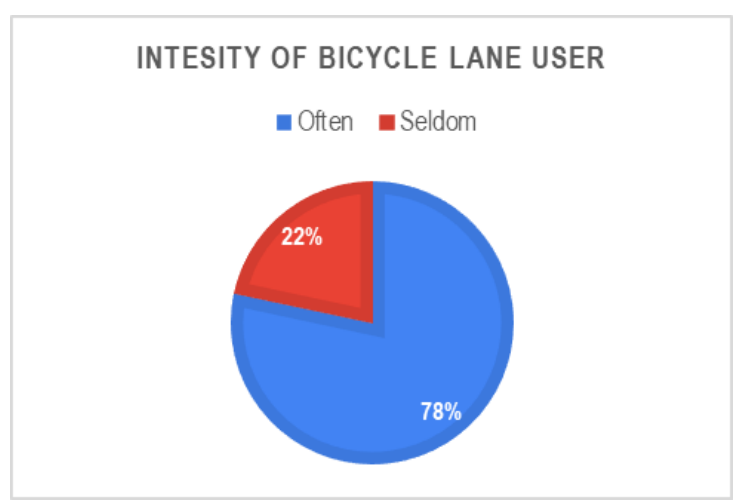

Figure 2. Intesity of bicycle lane user

Questionnaire data on the route Kambang Iwak Palembang Square.

Table 2. Questionare questions

\begin{tabular}{|c|l|c|c|}
\hline \multirow{2}{*}{ No } & \multicolumn{1}{|c|}{ Questions } & \multicolumn{2}{|c|}{ Result } \\
\cline { 3 - 4 } 1 & $\begin{array}{l}\text { Do you feel safe passing the } \\
\text { bike lane? }\end{array}$ & $53 \%$ & $47 \%$ \\
\hline 2 & $\begin{array}{l}\text { Do you feel comfortable } \\
\text { passing the bike lane? }\end{array}$ & $60 \%$ & $41 \%$ \\
\hline 3 & $\begin{array}{l}\text { Do you feel the bike lane } \\
\text { wide is adequate? }\end{array}$ & $56 \%$ & $47 \%$ \\
\hline 4 & $\begin{array}{l}\text { Does the movement of other } \\
\text { vehicles disturb cyclist } \\
\text { mobility? }\end{array}$ & $82 \%$ & $19 \%$ \\
\hline 5 & $\begin{array}{l}\text { Is the road paving at the } \\
\text { bike lane adequate already? }\end{array}$ & $54 \%$ & $46 \%$ \\
\hline
\end{tabular}

\subsection{The Effectiveness of Bicycle Lane}

The calculation of the analysis using the Bicycle Level Of Service (BLOS) method begins by calculating the number of vehicle flows per hour (Vma), the percentage of heavy vehicles (PHva), motor vehicle speed (Sra), the effective width of the outer lane (We) and the pavement condition rating $(\mathrm{Pc})$. The traffic volume 
(VMA) along the Kambak Iwak - Palembang Square route is known to be the most congested on Mondays, at 16.00-18.00 with a total of 11,177 vehicles/hour. Meanwhile, the busiest hour on Sunday is 16.00-18.00 with a total of 12,355 vehicles/hour. The most heavy vehicles (Phva) on the Kambak Iwak - Palembang Square route (Table 3) on Mondays are at 11.00-13.00 with a percentage of $0.17 \%$, while on Sundays at 11.00 13.00 with a total of $0.16 \%$.

Table 3. Percentage of Heavy Vehicles

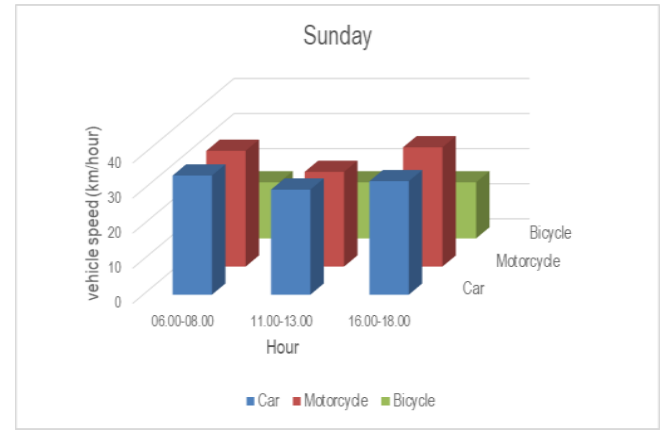

Figure 4. Vehicle speed on monday

\begin{tabular}{|c|c|c|c|c|c|c|c|c|}
\hline Day & Hour & $\begin{array}{l}\text { Bus } \\
\text { (unit) }\end{array}$ & $\begin{array}{c}\text { Vma } \\
\text { (vehicle/hour) }\end{array}$ & $\begin{array}{c}\text { Percentage } \\
(\%)\end{array}$ & $\begin{array}{l}\text { Light truck } \\
\text { (unit) }\end{array}$ & $\begin{array}{c}\text { Vma } \\
\text { (vehicle/hour }\end{array}$ & $\begin{array}{c}\text { Percentage } \\
(\%)\end{array}$ & $\begin{array}{c}\text { Heavy vehicle } \\
(\%)\end{array}$ \\
\hline \multirow{3}{*}{ Monday } & $06.00-08.00$ & 17 & 7060 & $0,24 \%$ & 39 & 7060 & $0,55 \%$ & $0,79 \%$ \\
\hline & $11.00-13.00$ & 19 & 11133 & $0,17 \%$ & 74 & 11133 & $0,66 \%$ & $0,84 \%$ \\
\hline & $16.00-18.00$ & 8 & 11177 & $0,07 \%$ & 49 & 11177 & $0,44 \%$ & $0,51 \%$ \\
\hline \multirow{3}{*}{ Sunday } & $06.00-08.00$ & 10 & 4882 & $0,20 \%$ & 26 & 4882 & $0,53 \%$ & $0,74 \%$ \\
\hline & $11.00-13.00$ & 16 & 10084 & $0,16 \%$ & 23 & 10084 & $0,23 \%$ & $0,39 \%$ \\
\hline & $16.00-18.00$ & 7 & 12355 & $0,06 \%$ & 34 & 12355 & $0,28 \%$ & $0,33 \%$ \\
\hline
\end{tabular}

pavement condition rating $(\mathrm{Pc})$ on the road along the Kambak Iwak - Palembang Square route is Jl. Tasik - Jl. A. Rivai - Jl. POM IX - Jl. Angkatan 45- Jl. Ahmad Dahlan (Figure 3) based on the Survey has a score of 3 which means the condition of the road pavement is quite good (medium).

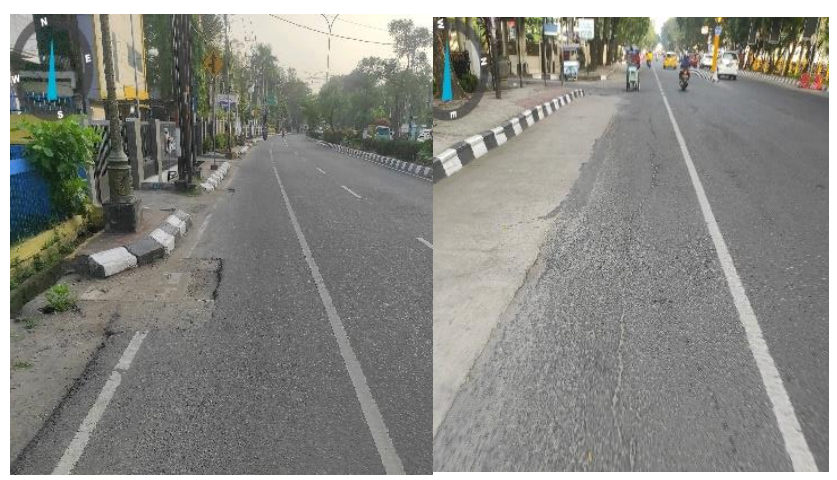

Figure 3. Pavement Condition

Vehicle Speed (SRA) on the road along the route Kambak Iwak - Palembang Square on Mondays and Sundays (Table 4). Vehicle speed on Monday is 34 $\mathrm{km} /$ hour for cars, $34 \mathrm{~km} /$ hour for motorcycles, and 16 $\mathrm{km} /$ hour for bicycles with the highest peak hours of vehicle flow being at 16.00-18.00 with a total of 11,177 vehicles/hour. Furthermore, the vehicle speed on Sunday is $34 \mathrm{~km} /$ hour for motorcycles, $34 \mathrm{~km} /$ hour for cars, and $16 \mathrm{~km} /$ hour for bicycles with the highest peak hours of vehicle flow being at 16.00-18.00 totaling 12,355 vehicles/hour.

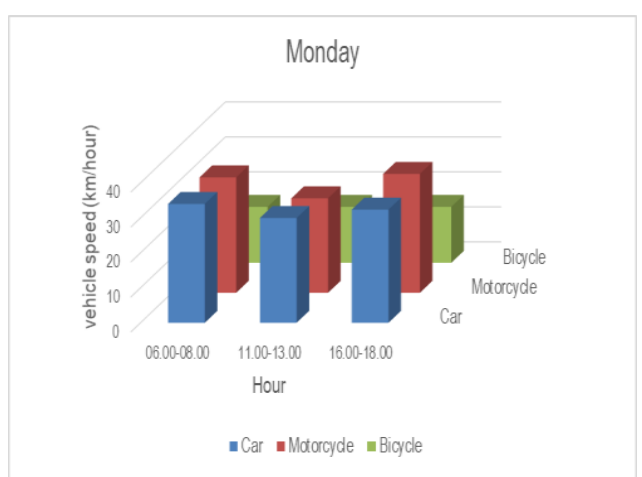

Figure 5. Vehicle speed on sunday

The average number of lanes (Nth) on the Kambak Iwak - Palembang Square route is 4 lanes. The bicycle lane width (Wbl) is $1.5 \mathrm{~m}$ and the travel lane width (Wol) is $8 \mathrm{~m}$. The width of the on-street parking road (PPK), the width of the pavement on-street parking (Wos), and the width of the adjusted pavement on-street parking (Wos') on the Kambang Iwak-Palembang Square route are not.

The results of the calculation of the existing road conditions are presented in Table 4. 
Table 4. Existing road condition

\begin{tabular}{|c|c|c|c|c|c|c|c|c|c|c|c|}
\hline Day & Hour & Vma & Phva & Pc & Sra & Nth & Ppk & Wos & Wos' & Wbl & Wol \\
\hline \multirow{3}{*}{ Monday } & $06.00-08.00$ & 7060 & $0,79 \%$ & 2 & 34 & 4 & 0 & 0 & 2 & 1,5 & 8 \\
\cline { 2 - 12 } & $11.00-13.00$ & 11133 & $0,84 \%$ & 2 & 30 & 4 & 0 & 0 & 2 & 1,5 & 8 \\
\cline { 2 - 12 } & $16.00-18.00$ & 11177 & $0,51 \%$ & 2 & 32 & 4 & 0 & 0 & 2 & 1,5 & 8 \\
\hline \multirow{3}{*}{ Sunday } & $06.00-08.00$ & 4882 & $0,74 \%$ & 2 & 34 & 4 & 0 & 0 & 2 & 1,5 & 8 \\
\cline { 2 - 11 } & $11.00-13.00$ & 10084 & $0,39 \%$ & 2 & 30 & 4 & 0 & 0 & 2 & 1,5 & 8 \\
\cline { 2 - 11 } & $16.00-18.00$ & 12355 & $0,33 \%$ & 2 & 32 & 4 & 0 & 0 & 2 & 1,5 & 8 \\
\hline
\end{tabular}

Where:

Vma $=$ Total Vehicle Flow (Number of vehicles/hour)

PHva = Percenatge of heavy vehicles (\%)

$\mathrm{Pc} \quad=$ Pavement condition rating

Sra = Motorized vehicle speed $(\mathrm{Km} / \mathrm{jam})$

Nth = Number of lanes in one way of travel (Lane)

PPK = The width of the on-street parking road

Wos = the width of the pavement on-street parking

Wos' = the width of the adjusted pavement on-street parking

$\mathrm{Wbl}=$ the width of bike lane

Wol = The width of the travel lane

Based on the results of the analysis using the Bicycle Level Of Service (BLOS) method on the Kambang Iwak - Palembang Square route, Palembang City, on Mondays and Sundays (Table 5), the BLOS value on weekdays (Mondays) had the BLOS ratings at 06.00-08.00 which is "E" or less than 5.5. This indicates that the The environment is strongly poor for bicycle (unacceptable by experienced cyclist and basic cyclist). Beside that, the BLOS value on weekdays (Mondays) had the BLOS ratings at $11.00-13.00$ and $16.00-18.00$ which is "F" or more than 5.5. This indicates that the The environment is unsafe for bicycle (not suitable for any cyclist). Meanwhile, the "F" rating on Sundays occurred at 16.00 -18.00 due to the congestion of vehicles so that cyclists feel less comfortable cycling along the Kambang Iwak -
Palembang Square route as the large volume of motorized vehicles which are dominated by private vehicles. On Sundays, the BLOS "F" value occurred at 06.00-08.00, 11.00-13.00 and $16.00-18.00$ with a total of 4,822 vehicles/hour, 10084 vehicles/hour , 12355 vehicles/hour and It indicates that The environment is unsafe for bicycle (not suitable for any cyclist). The main priority in handling bicycle lanes is the comfort factor and safety factor for cyclists. This is considering that these factors bring comfort to cyclists when cycling. Motor vehicles in this case are known to still dominate so that the implementation of the use of bicycle lanes is still experiencing problems. Therefore, the implementation of bicycle lanes will certainly not succeed without efforts to reduce the volume of private motorized vehicles.

Table 5. BLOS Results

\begin{tabular}{|c|c|c|c|c|c|c|c|c|}
\hline Day & Hour & Coefficient & Fv & Fs & Fp & Fw & \multicolumn{2}{c}{ Level of Service } \\
\hline & & & & & & & Score & Letter \\
\hline Monday & $06.00-08.00$ & 0,76 & 2,03 & 1,52 & 1,77 & $-0,66$ & 5,41 & $\mathrm{E}$ \\
\hline & $11.00-13.00$ & 0,76 & 3,55 & 1,08 & 1,77 & $-0,66$ & 6,49 & $\mathrm{~F}$ \\
\hline & $16.00-18.00$ & 0,76 & 3,55 & 1,29 & 1,77 & $-0,66$ & 6,70 & $\mathrm{~F}$ \\
\hline Sunday & $06.00-08.00$ & 0,76 & 3,04 & 1,51 & 1,77 & $-0,66$ & 6,42 & $\mathrm{~F}$ \\
\hline & $11.00-13.00$ & 0,76 & 3,55 & 1,06 & 1,77 & $-0,66$ & 6,48 & $\mathrm{~F}$ \\
\hline & $16.00-18.00$ & 0,76 & 3,55 & 1,28 & 1,77 & $-0,66$ & 6,70 & $\mathrm{~F}$ \\
\hline
\end{tabular}

\section{CONCLUSION}

Based on the results of calculations and analysis of the effectiveness of the bicycle lane service level in the city of Palembang, especially the Kambang Iwak Palembang Square route using the BLOS (Bicycle Level Of Service) method, it is known that the average BLOS value on Monday and Sunday is more than 5.5. This indicates that the environment is not safe for cyclists due to the dominant traffic volume being filled with motorized vehicles during weekdays, especially private vehicles. Furthermore, the BLOS scores on Monday at $06.00-$ 08.00 and $11.00-13.00$ are $4.5-5.5$ which indicates that the environment has insufficient space for cyclists. The amount of traffic flow in the city of Palembang, especially on the Kambang Iwak - Palembang Square route, is high. This causes cyclists cannot feel comfortable when cycling. The Palembang city government is advised to not only provide bicycle lane routes, but more than that, they must pay attention to 
comfort for cyclists or those who use non-motorized vehicles. This can be realized by developing facilities and infrastructure to support bicycle lanes, integrating with public transportation, and implementing adequate public transportation so that the number of the private vehicle can be reduced.

\section{ACKNOWLEDGMENTS}

The research presented in this paper was supported by Polytechnic State of Sriwijaya.

\section{REFERENCES}

[1] Artiningsih, M. Muktial, R. Kirana, and R. Kusumaningrum, "Kajian peluang penerapan jalur khusus sepeda di kota padang," Riptek, vol. 5, no. November 2011, pp. 1-7, 2018.

[2] N. Praditya, E. Rahmadona, S. Sudarmadji, and A. S. Pratama, "Karakteristik Pengguna Sepeda Lipat Terhadap Pemilihan Moda Transportasi Di Kota Palembang," Bear. J. Penelit. dan Kaji. Tek. Sipil, vol. 6, no. 4, pp. 218-225, 2021, doi: 10.32502/jbearing.3216202064.

[3] UU No. 22 Tahun 2009, "UU no.22 tahun 2009.pdf." p. 203, 2009.

[4] G. Fadly, S. Widodo, and S. Mayuni, "Analisis
Efektivitas Lajur Khusus Sepeda pada Kawasan Perkotaan Pontianak Studi Kasus ( Jalan Gusti Sulung Lelanang - Kh. Ahmad Dahlan - Johar Hos Cokroaminoto)," J. PWK, Laut, Sipil, Tambang, vol. 7, no. 1, pp. 1-8, 2020.

[5] B. Tripoli, R. Djamaluddin, and J. Amin, "Efektifitas Kinerja Lajur Khusus Sepeda Di Kawasan Kota Meulaboh," J. Tek. Sipil, vol. 1, no. 1, pp. 13-24, 2018.

[6] H. H. Sugasta, S. Widodo, and S. Mayuni, "Analisis Efektivitas Lajur Khusus Sepeda Pada Kawasan Perkotaan Pontianak ( Studi Kasus Jalan Sutan Syahrir - Jalan Jendral Urip - Jalan K. H. W. Hasyim - Jalan Merdeka)," J. Rekayasa Sipil, vol. 4, no. 4, pp. 1-9, 2016, [Online]. Available:

http://jurnal.untan.ac.id/index.php/JMHMS/artic le/view/19197.

[7] S. Ayu Iskandar et al., "Ge-STRAM: Jurnal Perencanaan dan Rekayasa Sipil Analisis Efektifitas Jalur Sepeda Berdasarkan Metode Bicycle Level Of Service (BLOS).”

[8] "Evaluasi Efektivitas Penyediaan Jalur Sepeda pada Jalan Perkotaan KONFERENSI REGIONAL TEKNIK JALAN KE-14," no. April 2018, 2020. 